\title{
Karakteristik Kimia Pempek Akibat Penambahan Konsentrasi Ekstrak Kulit Buah Naga Dan Metode Penyimpanan
}

\section{Chemical Characteristics Of Pempek Due To Addition Of Dragon Skin Extract Concentration And Storage Method}

\author{
Anak Agung Putu Sri Mahayani ${ }^{1}$, Amelia Nirmalawaty ${ }^{2}$ \\ Universitas 17 Agustus 1945 Surabaya, Jl. Semolowaru 45 Surabaya \\ Email: putusrimahayani@untag-sby.ac.id ${ }^{1}$
}

\begin{abstract}
Abstrak
Umumnya bagian buah naga yang dimanfaatkan hanya daging buahnya saja untuk dikonsumsi secara langsung maupun diolah sebagai produk pangan lainnya, sedangkan bagian kulitnya dibuang begitu saja. Berdasarkan beberapa hasil penelitian, kulit buah naga merah kaya akan sumber polyphenol dan antioksidan. Aktivitas antioksidan kulit buah naga merah lebih besar dibandingkan aktivitas di daging buahnya, sehingga kulit buah naga dapat dijadikan sebagai obat herbal alami dengan memanfaatkan antioksidan di dalam. Semakin ditambahkan ekstrak kulit buah naga maka daya simpan pempek lebih lama dibandingkan tanpa penambahan ekstrak kulit buah naga (kontrol) penggunaan plastik vacuum dapat meningkatkan masa simpan pempek.
\end{abstract}

Kata Kunci: ekstrak kulit buah naga, pempek, sifat fisik, sifat kimia

\section{Abstract}

The part of dragon fruit that is used is only the flesh of the fruit for direct consumption or processing as other food products, while the peel is just thrown away. Based on several research results, red dragon fruit peel is a rich source of polyphenols and antioxidants. The antioxidant activity of the red dragon fruit peel is greater than the activity in the flesh, so the dragon fruit peel can be used as a natural herbal medicine by utilizing the antioxidants inside. The more dragon fruit peel extract is added, the pempek's shelf life is longer than without the addition of dragon fruit peel extract (control), the use of vacuum plastic can increase the shelf life of pempek.

Keywords: dragon fruit peel extract, pempek, physical properties, chemical properties

\section{PENDAHULUAN}

Bagian yang dapat dikonsumsi (edible part) dari buah naga $\pm 74-75 \%$ dari berat keseluruhannya. Edible part ini dikenal sebagai sehingga daging buah, sedangkan prosentase kulit buah yang terdiri dari kulit dan scrap (sisik), berkisar 25 - 26\% (Sari dan Hardiyanti, 2013) dari berat keseluruhannya. Kondisi ini berarti potensi pemanfaatan kulit buah naga sebagai bahan tambahan pangan atau minuman cukup menjanjikan. Hal ini didukung hasil penelitian beberapa pakar, antara lain $\mathrm{Wu}$ et al. (2005), Nurliyana et al. (2010), dan lainlain yang menyatakan bahwa kulit buah naga mengandung antioksidan yang lebih tinggi dibandingkan daging buahnya, disampingkan dengan lemak dan karbohidrat yang lebih rendah dibandingkan daging buahnya (Sari dan Hardiyanti, 2013).

Pemanfaatan tepung kulit buah naga sebagai substitusi tepung terigu menghasilkan kue kering yang kurang memuaskan karena daya kembang kue kering menurun sehingga kue yang semakin keras (Triwulandariet al., 2017; Nirmalawaty dan Mahayani, 2019). Upaya pemanfaatan sebagai minuman (beverage) kurang memuaskan, hasil penelitian Waladi et al. (2015) menyimpulkan penambahan bubur kulit buah naga pada es krim mengakibatkan penurunan over run (daya kembang es krim), meningkatkan kadar serat dan waktu leleh serta berpengaruh negatif pada rasa dan tekstur es krim sedangkan hasil penelitian Adhayanti dan Ahmad (2020) menyatakan minuman instan kulit buah naga melalui metode pengeringan dingin (freezedryer) menghasilkan warna, kadar air, dan kadar antioksidan serta kelarutan yang lebih baik dibandingkan minuman instan yang dikeringkan secara 
konvensional. Berdasarkan kedua penelitian tersebut dapat disimpulkan bahwa pemanfaatan kulit buah naga sebagai bahan dasar minuman memerlukan teknologi dan biaya yang cukup besar agar antioksidan yang dikandungnya dapat dimanfaatkan secara optimal dan hanya dapat dilakukan oleh industri menengah sampai besar.

Pempek merupakan makanan tradisional dari Palembang yang terbuat dari daging ikan giling yang dicampur dengan air, tepung tapioka dan bahan lainnya. Pempek diperkirakan berasal dari Tionghoa dan masuk ke Palembang pada abad 16 dan saat ini telah menjadi oleh-oleh khas dari daerah tersebut. Sayangnyam masa simpan pempek sangat pendek yaitu hanya 16 jam saja bila disimpan pada suhu ruang baik dalam kemasan vakum maupun tidak vakum. Umur simpan dapat diperpanjang bila disimpan dalam suhu dingin (Pratama et al., 2016). Hal ini menjadi kendala pendistribusian pempek ke luar daerah Palembang baik melalui transportasi darat maupun udara yang harus ditempuh lebih dari 10 jam perjalanan, akibatnya perlu dilakukan penambahan bahan pengawet untuk memperpanjang masa simpannya.

Bahan pengawet dan antioksidan sintesis yang lazim digunakan oleh pengusaha makanan adalah formalin, asam benzoate, BHA (Butilated Hydroxyanisol), BHT (Butilated Hydroxytoluene) dan TBHQ (Tertier Butilated Hydroxyanisole). Penggunaan antioksidan dan pengawet dalam waktu lama tidak disarankan dan tidak direkomendasikan oleh Badan Pengawas Obat dan Makanan karena diduga dapat menimbulkan peradangan sampai kerusakan hati dan meningkatkan resiko penyakit karsinogenesis (Barus, 2009; Parwata, 2016).

Keadaan tersebut dapat diatasi dengan pemberian bahan pengawet dan antioksidan yang bersumber dari alam. Pada penelitian ini diujicobakan kulit buah naga merah sebagai bahan pengawet dan antioksidan alami. Pemilihan kulit buah naga merah didasari cukup besarnya proporsi kulit dan sisik buah naga yaitu sebesar $25-26 \%$ dari berat totalnya (Sari dan Hardiyanti, 2013) dan kandungan vitamin $\mathrm{C}$ yang lebih tinggi dibadingkan daging buahnya. Noor et al. (2016) menambahkan, selain mengandung vitamin $C$, kulit buah naga merah juga mengandung flavonoid, tanin, alkaloid, steroid, dan saponin.

Oktiarni et al. (2012) menyimpukan bahwa ekstrak kulit buah naga merah dapat memperpanjang masa simpan mie basah, dimana ekstrak segar kulit buah naga 25 $\mathrm{ml} / 50 \mathrm{ml}$ dapat disimpan selama 43 jam sedang perlakuan kontrol hanya selama 38 jam saja, bila kulit buah naga direbus terlebih dahulu baru diekstrak, masa simpan mie basah matang hanya bertahan selama 39 jam saja.

Disamping menggunakan bahan pengawet makanan, upaya meningkatkan masa simpan dapat dilakukan dengan penyimpanan produk pangan dalam kemasan vakum, yaitu dalam plastik poly ethylene nylon yang telah dilaminasi ketiga sisinya dan kedap udara sehingga aman digunakan untuk makanan dan minuman

Beberapa informasi diatas mendorong dilakukannya penelitian penambahan ekstrak segar kulit buah naga pada pempek. Tujuan penelitian ini mengetahui perubahan masa simpan pempek dengan penambahan esktrak segar kulit buah naga yang disimpan dalam kemasan vakum dan tidak vakum.

Belum optimalnya pemanfaatan antioksidan kulit buah naga mendorong dilakukannya penelitian pemanfaatannya sebagai pengawet produk pangan secara alami. Hasil penelitian Oktiarni et al. (2012) pada mie basah menyimpukan bahwa penggunaan ekstrak segar kulit buah naga sebesar $25 \mathrm{ml}: 50 \mathrm{ml} \quad(1: 2)$ meningkatkan mutu simpan, menghasilkan mie basah sesuai SNI dan tidak mempengaruhi organoleptiknya. Fenomena yang hamper sama juga ditemukan oleh Paradhita (2018) pada bakso. Bila esktrak berasal dari kulit buah naga kering, maka tidak berpengaruh pada mutu simpan nugget (Anjarsari, 2017). Produk pangan setengah matang, seperti pempek, bakso, nugget atau sosis umumnya dikemas dalam kemasan plastik baik dalam 
kondisi tidak divakum maupun divakum. Kemasan plastic vakum umumnya dapat meningkatkan masa simpan produk karena terbatasnya oksigen dalam kemasan sehingga dapat menghambat laju oksidasi produk pangan. Pada penelitian ini diharapkan penambahan ekstrak kulit buah naga dapat memperpanjang masa simpan pempek baik yang disimpan dalam keadaan vakum maupun tidak. Diharapkan hasil penelitian dapat mengembangkan pengawet alami dari hasil samping produk pangan.

\section{METODE}

Penelitian akan dilaksanakan di Laboratorium Pangan Terpadu Fakultas
Vokasi Universitas 17 Agustus 1945 Surabaya pada bulan Juli- Desember 2020.

Rancangan percobaan yang digunakan adalah Rancangan Acak Lengkap pola factorial. Faktor pertama adalah4 taraf konsentrasi ekstrak segar kulit buah naga merah $(0 \%, 25 \%, 50 \%$ dan $75 \%)$ dan Faktor kedua adalah 2 taraf kondisi kemasan (Vakum dan tidak vakum). Masing-masing kombinasi perlakuan diulang3 kali.

Pembuatan ekstrak kulit buah naga:

$250(\mathrm{~g})$ buah naga ditambahkan air mineral 250(ml) kemudian diblender selanjutnya disaring maka ekstrak kulit buah naga $(0,25$, 50 dan $75 \mathrm{ml})$ ditambah air mineral samai $100(\mathrm{ml})$.

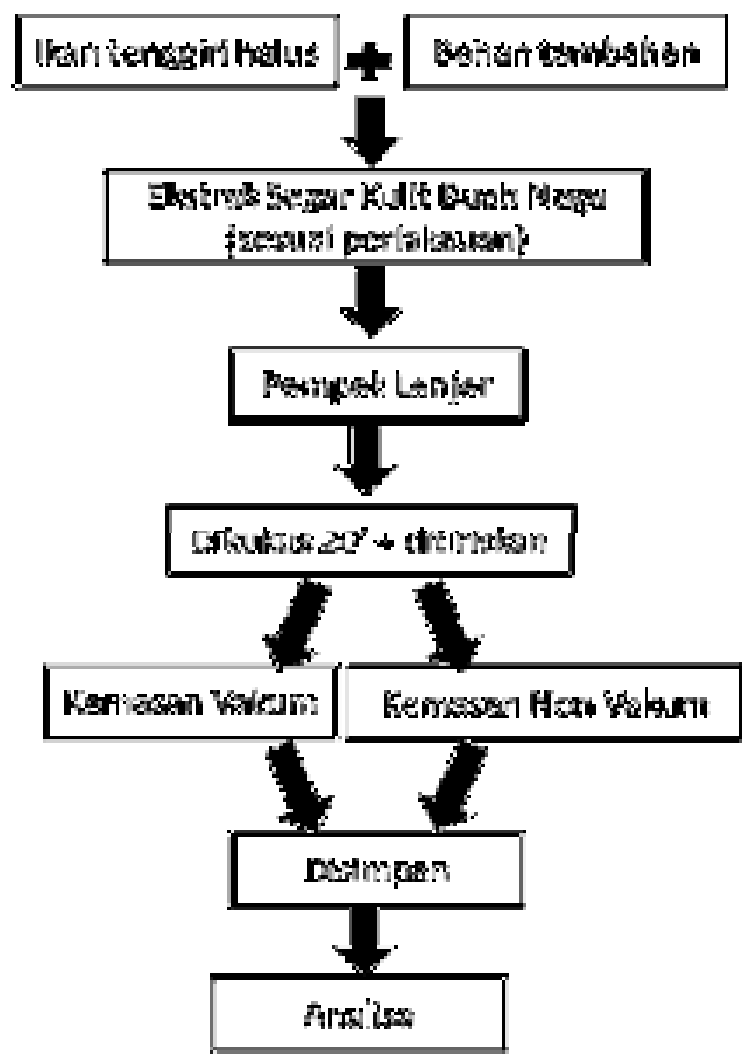

Gambar 1. Diagram Alir Pembuatan Pempek 
Tabel 1. Komposisi Pempek pada Empat Taraf Ekstrak Segar Kulit Buah Naga

\begin{tabular}{|c|c|c|c|c|}
\hline \multirow{2}{*}{ Bahan } & \multicolumn{4}{|c|}{ Ekstrak Segar Kulit Buah Naga } \\
\cline { 2 - 5 } & $\mathbf{0 \%}$ & $\mathbf{2 5 \%}$ & $\mathbf{5 0 \%}$ & $\mathbf{7 5 \%}$ \\
\hline Daging ikan tenggiri $(\mathrm{g})$ & 125 & 200 & 200 & 200 \\
\hline Ekstrak segar kulit buah naga $(\mathrm{ml})$ & $0 \mathrm{ml} / 50 \mathrm{ml}$ & $12,5 \mathrm{ml} / 50 \mathrm{ml}$ & $25 \mathrm{ml} / 50 \mathrm{ml}$ & $37,5 \mathrm{ml} / 50 \mathrm{ml}$ \\
\hline Garam $(\mathrm{g})$ & 7,5 & 7,5 & 7,5 & 7,5 \\
\hline Tepung tapioka $(\mathrm{g})$ & 95 & 95 & 95 & 95 \\
\hline Tepung terigu $(\mathrm{g})$ & 25 & 25 & 25 & 25 \\
\hline Bawang putih $(\mathrm{g})$ & 6,5 & 6,5 & 6,5 & 6,5 \\
\hline
\end{tabular}

\section{HASIL DAN PEMBAHASAN}

Penambahan ekstrak segar kulit buah naga meningkatkan secara nyata masa simpan pempek dalam kemasan tidak vakum, dimana penambahan esktrak sebesar $50 \%$ dan $75 \%$ meningkatkan masa simpan 2 kali lipat dibandingkan perlakuan kontrol. Pada perlakuan kemasan vakum, penambahan $25 \%$ ekstrak tidak berbeda nyata dengan perlakuan control dan tidak adanya perbedaan yang nyata pada semua perlakuan penambahan ekstrak segar kulit buah naga.

\section{PROTEIN}

a. Sebelum penyimpanan

\begin{tabular}{|c|r|c|c|c|c|}
\hline SK & DB & JK & KT & $\begin{array}{c}\text { F- } \\
\text { HIT }\end{array}$ & $\begin{array}{c}\text { F- } \\
\text { TABEL }\end{array}$ \\
\hline $\begin{array}{c}\text { Perlakua } \\
\text { n }\end{array}$ & 3 & 0.185 & 0.062 & $\mathbf{0 . 8 4 2}$ & 4.07 \\
\hline Galat & 8 & 0.586 & 0.073 & & \\
\hline Total & 11 & 0.771 & & & \\
\hline
\end{tabular}

Penambahan ekstrak kulit buah naga tidak berpengaruh pada kadar protein pempek

b. Sesudah penyimpanan

\begin{tabular}{|c|r|c|c|r|r|}
\hline SK & db & JK & KT & F-hit & \multicolumn{1}{c|}{ F-tab } \\
\hline Perlakuan & 7 & 7.814 & 1.116 & $\mathbf{8 . 6 0 4}$ & 4.03 \\
\hline V & 1 & 0.059 & 0.059 & 0.451 & 8.53 \\
\hline K & 3 & 3.088 & 1.029 & 7.935 & 5.29 \\
\hline V/K & 3 & 4.668 & 1.556 & $\mathbf{1 1 . 9 9 2}$ & 5.29 \\
\hline Galat & 16 & 2.076 & 0.130 & & \\
\hline Total & 23 & 9.890 & & & \\
\hline
\end{tabular}

Perlakuan penambahan ekstrak segar kulit buah naga berpengaruh nyata pada kadar protein. Terjadi interaksi antara macam kemasan dan konsentrasi ekstrak segar kulit buah naga.

\begin{tabular}{|c|rc|}
\hline Perlakuan & \multicolumn{2}{|c|}{ Rata-2 Protein } \\
\hline K0V1 & 8.94 & $\mathrm{ab}$ \\
\hline K1V1 & 8.94 & $\mathrm{ab}$ \\
\hline K2V1 & 9.36 & $\mathrm{~b}$ \\
\hline K3V1 & 8.51 & $\mathrm{a}$ \\
\hline K0V2 & 8.18 & $\mathrm{a}$ \\
\hline K1V2 & 8.65 & $\mathrm{a}$ \\
\hline K2V2 & 9.12 & $\mathrm{~b}$ \\
\hline K3V2 & 9.40 & $\mathrm{~b}$ \\
\hline BNJ 5\% & 1.019 & \\
\hline SD & 0.313 & \\
\hline
\end{tabular}

Kemasan non vakum, kadar protein tertinggi pada protein konsentrasi 50\% tetapi tidak berbeda nyata dengan perlakuan control dan konsentrasi $25 \%$, sedangkan pada kemasan vakum semakin tinggi konsentrasi ekstrak segar kulit buah naga, kadar protein semakin tinggi

Data diatas pengemasan berperan dalam mencegah terjadinya penurunan protein. Sehingga penggunaan kemasan harus benar- benar sesuai dengan produk yang akan kita kemas. Menurut Syarief at all (1989) menyebutkan bahwa penggunan 13lastic pada makanan cukup menarik karena sifat-sifatnya yang menguntungkan seperti luwes, mudah dibentuk mempunyai adaptasi yang tinggi terhadap produk, tidak korosif seperti wadah logam, serta mudah dalam penggunaannya. Menurut Winarno (1992) merupakan hasil hidrolisis yang ringan sedangkan protein sekunder adalah 
hasil hidrolisis yang berat. Protein terkoagulasi dari hasil denaturasi protein oleh panas atau alcohol.

\section{LEMAK}

a. Sebelum penyimpanan

\begin{tabular}{|l|c|c|l|l|l|}
\hline \multicolumn{1}{|c|}{ SK } & DB & JK & KT & F-Hit & $\begin{array}{c}\text { F- } \\
\text { Tabel }\end{array}$ \\
\hline Perlakuan & 3 & 2.819 & 0.940 & $\mathbf{3 3 . 0 5 1}$ & 4.07 \\
\hline Galat & 8 & 0.227 & 0.028 & & \\
\hline Total & 11 & 3.046 & & & \\
\hline
\end{tabular}

Penambahan ekstrak kulit buah naga berpengaruh pada kadar lemak pempek

b. Sesudah penyimpanan

\begin{tabular}{|c|l|l|l|l|l|}
\hline SK & Db & JK & KT & F-hit & F-tab \\
\hline Perlakuan & 7 & 0.723 & 0.103 & 2.342 & 4.03 \\
\hline $\mathrm{V}$ & 1 & 0.076 & 0.076 & 1.655 & 8.53 \\
\hline $\mathrm{K}$ & 3 & 0.423 & 0.141 & 3.074 & 5.29 \\
\hline $\mathrm{V} / \mathrm{K}$ & 3 & 0.224 & 0.075 & 1.624 & 5.29 \\
\hline Galat & 16 & 0.705 & 0.044 & & \\
\hline Total & 23 & 1.428 & & & \\
\hline
\end{tabular}

Penambahan ekstrak segar kulit buah naga tidak berpengaruh pada kadar lemak.

\begin{tabular}{|c|c|}
\hline Perlakuan & Rata-rata lemak \\
\hline Kontrol & 0.910 \\
\hline $25 \%$ & 0.943 \\
\hline $50 \%$ & 1.238 \\
\hline $75 \%$ & 1.115 \\
\hline BNJ 5\% & tn \\
Sd & 0.210 \\
\hline Kemasan & \\
\hline Non Vakum & 1.108 \\
\hline Vakum & 0.995 \\
\hline BNJ 5\% & tn \\
Sd & 0.210 \\
\hline
\end{tabular}

Kadar lemak pada berbagai konsentrasi ekstrak kulit buah naga tidak berbeda nyata begitu pula kadar lemak pada kemasan vakum dan non vakum tidak berbeda nyata.

Data diatas secara alam trigiserida merupakan bentuk yang utama walaupun juga didapat mono dan di-gliserida. Gliserida mengandung asam lemak yang tidak jenuh mempunyai titik leleh yang lebih rendah daripada gliresida yang mengandung asam lemak jenuh (Hadiwiyoto, 1983)

\section{KADAR AIR}

a. Sebelum Penyimpanan

\begin{tabular}{|c|c|c|c|c|r|}
\hline SK & DB & JK & KT & F-Hit & $\begin{array}{c}\text { F- } \\
\text { Tabel }\end{array}$ \\
\hline Perlakuan & 3 & 265.801 & 88.600 & $\mathbf{2 0 . 0 7 5}$ & 4.07 \\
\hline Galat & 8 & 35.307 & 4.413 & & \\
\hline Total & 11 & 301.108 & & & \\
& & & & & \\
\hline
\end{tabular}

Kadar air perlakuan kontrol lebih tinggi dan berbeda nyata dengan perlakuan penambahan ekstrak kulit buah naga

b. Sesudah

\begin{tabular}{|c|r|r|r|c|r|}
\hline SK & $\mathrm{db}$ & \multicolumn{1}{c|}{ JK } & KT & F-hit & F-tab \\
\hline Perlakuan & 7 & 210.777 & 30.111 & $\mathbf{7 . 9 0 6}$ & 4.03 \\
\hline $\mathrm{V}$ & 1 & 0.901 & 0.901 & 0.237 & 8.53 \\
\hline $\mathrm{K}$ & 3 & 110.862 & 36.954 & $\mathbf{9 . 7 0 3}$ & 5.29 \\
\hline $\mathrm{V} / \mathrm{K}$ & 3 & 99.014 & 33.005 & $\mathbf{8 . 6 6 6}$ & 5.29 \\
\hline Galat & 16 & 60.937 & 3.809 & & \\
\hline Total & 23 & 271.714 & & & \\
\hline
\end{tabular}

Penambahan ekstrak segar kulit buah naga berpengaruh nyata pada kadar air pempek, dimana perlakuan konsentrasi dan interaksi kondisi kemasan dengan konsentrasi berpengaruh nyata terhadap kadar air pempek.

Perlakuan control dalam kemasan non vakum dan penambahan esktrak segar $50 \%$ dalam kemasan vakum terjadi penurunan kadar air dibandingkan sebelum penyimpanan.

Kadar air tertinggi pada perlakuan penambahan ekstrak segar $75 \%$ dalam kemasan vakum dan kadar air terendahpada penambahan $50 \%$ ekstrak segar dalam kemasan vakum.

Data diatas protein yang telah mengalami koagulasi dimana ikatan gugus reaktif protein tersebut menahan seluruh cairan sehingga terbentuk gel (Winanrno, 
1994). Untuk mencari kadar air dengan pemanasan $100-105^{\circ} \mathrm{C}$ selama 3 jam atau sampai didapat berat yang konstan selisih berat sebelum dan sesudah pengeringan merupakan banyak air yang diuapkan .

VITAMIN C

a. Ekstrak kulit buah naga

\begin{tabular}{|c|c|}
\hline Perlakuan & Kadar vitamin C $(\mathrm{mg} / \mathrm{g})$ \\
\hline $25 \%$ & 3.89 \\
\hline $50 \%$ & 5.80 \\
\hline $75 \%$ & 7.71 \\
\hline
\end{tabular}

Asumsi Kehilangan Vitamin C setelah perebusan pempek

\begin{tabular}{|l|l|l|l|l|}
\hline Perlakuan & Kontrol & $25 \%$ & $50 \%$ & $75 \%$ \\
\hline Awal & & 3.89 & 5.80 & 7.71 \\
\hline Setelah masak & 0.01 & 2.45 & 3.30 & 5.68 \\
\hline Kehilangan & & 1.44 & 2.50 & 2.03 \\
\hline $\begin{array}{l}\text { Setelah } \\
\text { penyimpanan }\end{array}$ & 0.01 & 2.02 & 3.05 & 4.16 \\
\hline Kehilangan & 0.00 & 0.43 & 0.25 & 52 \\
\hline
\end{tabular}

Rata-rata kehilangan vitamin C setelah dimasak sebesar $1.99 \mathrm{mg} / \mathrm{g}$ adonan pempek, setelah disimpan dan mengalami kerusakan, kehilangan vitamin $\mathrm{C}$ pada perlakuan $25 \%$ lebih besar dibandingkan perlakuan 50\% akibatnya pempek perlakuan $25 \%$ lebih cepat rusak dibandingkan perlakuan $50 \%$ dan $75 \%$. Meskipun kehilangan vitamin $\mathrm{C}$ pada perlakuan $75 \%$ lebih tinggi dibandingkan perlakuan $50 \%$ masa simpan perlakuan $75 \%$ paling lama yang disebabkan kadar vitamin $\mathrm{C}$ awal hampir 2 x lipat perlakuan konsentrasi $50 \%$.

a. Sebelum

\begin{tabular}{|c|c|c|c|c|r|}
\hline SK & DB & JK & KT & F-Hit & F-Tabel \\
\hline Perlakuan & 3 & 49.238 & 16.413 & $\mathbf{1 6 6 8 . 3 6 3}$ & 4.07 \\
\hline Galat & 8 & 0.079 & 0.0098 & & \\
\hline Total & 11 & 49.316 & & & \\
\hline
\end{tabular}

Penambahan ekstrak kulit buah naga berpengaruh pada kadar vitamin $\mathrm{C}$ pempek

\begin{tabular}{|c|cc|}
\hline Perlakuan & \multicolumn{2}{|c|}{ Rata-2 kadar air } \\
\hline Kontrol & 0.01 & a \\
\hline $25 \%$ & 2.45 & b \\
\hline $50 \%$ & 3.30 & c \\
\hline $75 \%$ & 5.68 & d \\
\hline BNJ 5\% & 0.199 & \\
\hline SD & \multicolumn{2}{|c|}{0.099} \\
\hline
\end{tabular}

Semakin tinggi konsentrasi ekstrak kulit buah naga yang diberikan kadar vitamin $\mathrm{C}$ meningkat secara nyata

b. Sesudah

\begin{tabular}{|c|r|r|r|r|r|}
\hline SK & db & \multicolumn{1}{c|}{ JK } & KT & F-hit & F-tab \\
\hline Perlakuan & 7 & 56.379 & 8.054 & $\mathbf{2 4 6 . 5 1 6}$ & 4.03 \\
\hline $\mathrm{V}$ & 1 & 0.021 & 0.021 & 0.634 & 8.53 \\
\hline $\mathrm{K}$ & 3 & 55.979 & 18.660 & $\mathbf{5 7 1 . 1 2 2}$ & 5.29 \\
\hline $\mathrm{V} / \mathrm{K}$ & 3 & 0.379 & 0.126 & 3.870 & 5.29 \\
\hline Galat & 16 & 0.523 & 0.033 & & \\
\hline Total & 23 & 56.902 & & & \\
\hline
\end{tabular}

Penambahan ekstrak segar kulit buah naga berpengaruh nyata pada kadar air pempek, dimana perlakuan konsentrasi berpengaruh nyata terhadap kadar vitamin C pempek

\begin{tabular}{|c|c|}
\hline Perlakuan & Rata-rata Vitamin C \\
\hline Kontrol & $0.010 \mathrm{a}$ \\
\hline $25 \%$ & $2.023 \mathrm{~b}$ \\
\hline $50 \%$ & $3.048 \mathrm{c}$ \\
\hline $75 \%$ & $4.158 \mathrm{~d}$ \\
\hline BNJ 5\% & 0.362 \\
Sd & 0.181 \\
\hline Kemasan & \\
\hline Non Vakum & 2.237 \\
\hline Vakum & 2.280 \\
\hline BNJ 5\% & tn \\
Sd & 0.181 \\
\hline
\end{tabular}

Semakin tinggi konsentrasi ekstrak segar kulit buah naga yang diberikan, kadar vitamin $\mathrm{C}$ semakin tinggi pula dan berbeda nyata secara statistic, dimana kadar vitamin $\mathrm{C}$ tertinggi terdapat pada perlakuan $75 \%$. 
Menurut data diatas asam askorbat bersifat larut dalam air yang merupakan produk dari gula heksosa dan kiti telah diisolasi dan disintesa secara kimiawi. Asam askorbat sering ditambahkan dalam produk pangan sebagai antioksidan untuk mencegah terjadinya oksidasi, asam askorbat juga berfungsi sebagai penstabil warna dan cita rasa (Winarno, 1994).

\section{SIMPULAN DAN SARAN}

Kesimpulan dari penelitian adalah penambahan ekstrak segar kulit buah naga terhadap protein, lemak, kadar air dan vitamin $\mathrm{C}$ meningkat secara nyata masa simpan pempek dalam kemasan tidak vakum dimana penambahan ekstrak sebesar $50 \%$ dan $75 \%$ meningkatkan masa simpan 2 kali lipat dibandingkan perlakuan kontrol.

Perlu dilakukan penelitian lanjutan guna mengetahui perubahan jumlah koloni bakteri dalam pempek setelah diberi ekstrak segar kulit buah naga.

\section{UCAPAN TERIMA KASIH}

Penelitian ini didanai hibah Perguruan Tinggi, untuk itu kami sampaikan ucapan terima kasih disampaikan pada Universitas 17 Agustus 1945 Surabaya melalui Lembaga Penelitian dan Pengabdian Masyarakat serta Program Studi Agroindustri Fakultas Vokasi Universitas 17 Agustus 1945 Surabaya yang telah memberikan dukungan.

\section{DAFTAR PUSTAKA}

Andhayanti, I. dan T. Ahmad, 2020. Karakter mutu fisik dan kimia minuman instan kulit buah naga yang diproduksi dengan metode pengeringan yang berbeda. Media Farmasi Vol. XVI : $1: 57$ - 64, April $2020 . \quad$ http://journal.poltekkesmks.ac.id

Anjarsari, M., 2017. Karaktersitik Sosis dengan Penambahan Ekstrak Kulit Buah Naga Merah (Hylocereus polyrhizus)Selama Penyimpanan Suhu Ruang. Departemen Ilmu
Produksi danogor, Bogor. Skripsi. https://repository.ipb.ac.id

Astawan, 2012. Pempek, Nilai Gizi "Kapal Selam" Paling Tinggi. http://pustakapanganku.blogspot.com Handayani, P.A dan A. Rahmawati, 2012. Pemanfaatan kulit buah naga (dragon fruit) sebagai pewarna alami makanan pengganti pewarna sintetis. Jurnal Bahan Alam Terbarukan 1 (2): 19-24

Mayuri, S., A. Smita, dan Saudagar R.B, 2018. Dragon fruit as a nutraceuticals. World Journal of Pharmacy and Pharmaceutical Sciences Volume 7(4): $\quad$ 958-972. https://www.wjpps.com

Oktiarni, D., D. Ratnawati dan D.Z. Angraini, 2012. Pemanfaatan ekstrak kulit buah naga merah (Hylocereus polyrhizus sp.) sebagai pewarna dan pengawet alami mie basah. Jurnal Gradien Vol. 8 (2): 819 - 824 Juli 2012. https://ejournal.unib.ac.id

Prahadita, F.A., 2018. Pengaruh konsentrasisari kulit buah naga merah (Hylocereus polyrhizus) dan lama penyimpanan terhadap jumlah koloni bakteri bakso daging sapi sebagai sumber belajar biologi. Jurusan Pendidikan Biologi, Fakultas Keguruan Pelatihan dan Pendidikan, Universitas Muhammadiya Malang. Skripsi. http://eprints.umm.ac.id

Pratama, M., E. Warsiki dan L. Haditjaroko, 2016. Kinerja label untuk memprediksi umur simpan pempek pada berbagai kondisi penyimpanan. J. Teknologi Industri Pertanian 26 (3): 321 - 332. https://journal.ipb.ac.id

Rahmawati, B. dan E. Mahajoeno, 2009. Variation of morphology, isozymic and vitamin $C$ content of dragon . fruit varieties.Bioscience 1 (3): 131 - 137. https://eprints.uns.ac.id

Triwulandari, D., A. Mustofa dan M. Karyantina, 2017. Karakteristik fisikomia dan uji organoleptik cookies kulit buah naga (Hylocereus undatus) dengan substitusi tepung ampas tahu. 
Jitipari Vol 3(2): 61-66. https://ejurnal.unisri.ac.id.

Utami, Sri Fadhillah, 2019. 7 Simbol dan Jenis Plastik yang Perlu Kamu ketahui. https://zerowaste.id

Widyaningsih, T.D., N. Wijayanti, N.I.P. Nugrahini, 2016. Pangan Fungsional. UB Press, Malang218 hal.
Winarno. 1994. Kimia Pangan dan Gizi. Penerbit PT. Gramedia. Jakarta.

Wu Li-Chen, et,al. 2006.Antioxidant and Antiproliferative Activities of Red Pitaya. Food Chemistry 95 : 319-327. 